\title{
Connecting with Stakeholders
}

\section{Creative Marketing for Small Libraries}

By Susan Ebertz, Wartburg Theological Seminary; Megan West, Private Academic Library Network of Indiana; and Karl Stutzman, Anabaptist Mennonite Biblical Seminary

\begin{abstract}
Libraries with a small staff often lack budget and expertise to create outreach and marketing plans for their libraries, resources, and services. Yet small libraries also have unique opportunities: they can more easily adapt to a changing landscape and benefit from synergies across their various services. Karl Stutzman and Susan Ebertz, who manage small theological libraries, will share about their ongoing experiments with marketing and outreach. Special guest Megan West, Communications and Marketing Director at Private Academic Library Network of Indiana (PALNI), will share creative strategies and options for small libraries that are ready to up their marketing game. West has experience with communications and marketing in a variety of media through her work supporting the PALNI consortium. PALNI includes a number of small libraries and is working on an initiative to engage a variety of stakeholders at its supported libraries.
\end{abstract}

\section{PART ONE}

Welcome to our session this afternoon. I'm Karl Stutzman, library director at Anabaptist Mennonite Biblical Seminary in Elkhart, Indiana. Presenting with me today are Susan Ebertz, library director at Wartburg Theological Seminary in Dubuque, Iowa, and Megan West, communications and marketing director at Private Academic Library Network of Indiana.

In a digital age, libraries are more important than ever, but some folks falsely assume that libraries are becoming obsolete. Wellequipped libraries are no longer an assumed need for institutions 
of higher education. We need to connect with a variety of stakeholders-administrators, faculty, students, alumni-to tell the library's story and convince them of the ways it serves them and provides a real return on the large investment in resources and staff. As a stereotypically modest and nerdy librarian, I've had to learn how to do something called "marketing." Not only is it not my forte, I don't have an overabundance of time and money for this "other duty as assigned."

Our first speaker, Susan Ebertz, is an inspiration in her use of Facebook and media to promote her library.

\section{Susan Ebertz, Director for the Reu Memorial Library, Wartburg Theological Seminary}

The only thing I remember from the marketing class I took many years ago is the four Ps of the marketing mix. I don't know if it is current thinking. The four Ps are product, price, place, and promotion. I'm not going into the other three Ps. This is what we do with promotion.

During the semester, students working in the library are responsible for posting on Facebook and Twitter in the evenings when they work. They post on Facebook according to our schedule that we have set up.

- Monday: library photo. Something in the library (e.g., picture of the sunset through one of the windows). Once a month, a picture of the display in the entrance. These remind students of the physical library.

- Tuesday: resource. Something from the Research Tools web page (has links to our online databases). Tell what it is and why someone would use it. Link to the resource.

- Wednesday: book recommendation. Find a book we own. Tell what the book is about and why someone should read it. Include a picture.

- Thursday: throwback photo. We have an archives of pictures taken in the library. Alumni and students love seeing pictures of themselves and friends. This is one of the most popular posts.

- Friday: service. Some service that we do for students e.g. mailing books to distance students. Sometimes they are not aware of our services, and this post reminds them. 
- Saturday: new book. Highlight one of the books on the new book shelf with a picture and several sentences describing it. We have gotten comments from students about wanting to read a book highlighted in this way.

- Sunday: library hours for the week.

Other posts are done at other times and include information about upcoming library events or a report on an event.

On Twitter, we follow a schedule similar to Facebook. Since we can't schedule a tweet, we don't tweet every day. I have thought about using Hootsuite (https://hootsuite.com/\#) or something similar. But we haven't done so yet.

We use email for the following notices:

- Information about new resources to faculty and students. These are short emails, but enough to tantalize them to learn more about them. Faculty and students hate long emails and don't read them all. Bullet points are good.

- Current resources that students could use at a particular time in the semester. For example, reminding them about Zotero before their annotated bibliography is due.

- Events in the library. For example, announcing the used book sale several weeks ahead.

- Library hours if they are changing.

We sometimes target our email to a particular student population or to faculty only. It doesn't make sense to announce something to our distance students that only residential students can see or attend or care about.

We update the library web page regularly. The top portion includes library hours and upcoming events, depending on the time of year. There is a link to the library webpage from MyWTS. I show the students how to get to the library page from there.

After daily chapel, we have a time for announcements. We mainly use this for events or workshops. It helps if these announcements are funny to keep the students' attention.

I am thinking about sending out a monthly newsletter using elink https://elink.io/ and pocket https://getpocket.com/. I think that this might be especially useful for linking to databases and resources. 


\section{PART TWO}

As communications and marketing director for Private Academic Library Network of Indiana, Megan West has used her substantial skills with digital media and her marketing savvy to tell the story of a statewide consortium of small- to medium-sized academic libraries, including a number of seminaries. I've experienced Megan as a "marketing person" who understands the realities of small libraries. We are bringing Megan in on a video conference connection.

\section{Megan West, Digital Communications Manager, Private Academic Library Network of Indiana}

I've divided my talk into three different sections based on some of the most common pain points when it comes to library marketing.

1. "I need more skilled labor!"

2. "I need cost-effective print materials!"

3. "I need more confidence!"

The first pain point I'm going to address is, "I need more skilled labor!" This could also be called utilizing inside and outside resources. If you are at a college or university, an important inside resource is marketing or design student workers or interns. For schools that offer degrees in business and/or design, this is one of the easiest ways to get cheap labor: do a call out for students who are learning the skills.

However, they might be hard to find in a seminary that doesn't offer those degrees. In those cases, I'd suggest as a first step working with outside institutions. Contact marketing and design faculty at the larger schools around you to ask for interns, set up projects in for-credit classes, or offer options for students to complete their required capstone projects. Faculty love the chance to bring realworld work to their students, especially in 300-400-level courses. If you're turned down for a class project, you can ask for star students that would be interested in an internship. Faculty who are interested in doing a class project can make it a competition between groups or individual students.

First, decide what you need. Photography? Graphics? Video work? A marketing plan? That will inform which faculty members you contact. Class groups can present whole marketing plans to your 
staff. Or you could have the whole class put together content-videos and graphics, patron testimonials, usability testing, etc. When I was in school for marketing, one of my design classes brought in a business. They gave us all the information we needed to design something for them, and that was our last project that semester. The business gave me a $\$ 500$ scholarship when I won the logo competition. It was cool for me as the student, because it was my first paid work as a designer, and my professor mentored me through the experience. An added benefit of working with design students is that students know student behavior better than we do. They can act as a focus group that works for you.

When you can get help in these ways, it's fabulous, but much of the time the designing of content and marketing will fall to you personally. A few tools that our librarians use and love offer a significant educators' discount. Some examples of these tools include:

- Piktochart (piktochart.com): Piktochart offers a nonprofit and educational discount for pricing of only $\$ 40$ a year, which gives you high resolution infographics made for print. The free version will be fuzzy and have branding from Piktochart.

- Adobe Spark (https://spark.adobe.com/make/flyer-maker): I use Adobe products, but they have a steep learning curve and are costly. However, they just came out with something called "Adobe Spark" that is free for educators and super easy to use.

- Canva photo editor (https://www.canva.com/photo-editor/): This tool is great for social media posts.

I want to end this section by saying, don't just look at what other libraries are doing for content and design. I intentionally look at designs outside of the library world and adapt them for my consortium's purposes. For example, I like to look at designs from Fortune 500 companies, because they throw a ton of money at marketing. So, if I have a bunch of statistics I want to show, I'll google "Verizon Infographic" and I'll steal their layout or look at how they illustrated yearby-year comparisons, etc.

Some of you are still saying, "Megan, I might have time to do it during the summer or school breaks, but most of the time, I'm drowning." LibrarianDesignShare.org is a great resource. It's a place where librarians from all over submit their designs for free downloading 
and adapting. Everything from posters to designs for the web can be found here. It's great for general library needs, but you'll want something more customized for items given to stakeholders.

The second pain point to address is, "I need cost-effective print materials!" This is where PALNI sees its biggest bang for the buck. I'll cover materials first, and then print vendors that we like.

Some of our favorite items that we are going to expand on are our portable, pocket-size items for just-in-time outreach. We call these "what I do cards" and "service cards."

- "What I do" cards are business cards that actually inform people what you do. No one outside the library knows what a Technical Services Director does. But the backside lists the most common tasks that the general public can understand.

- These institutional repository cards are just one example of a service card. This is a kind of "elevator speech" for those that stink at elevator speeches. I suggest making one for each service and keeping them in a business card holder in your pocket or in your laptop case. The goal is to have just enough information to create awareness without too much information to overwhelm. Offer a link or contact information to go deeper.

Although tiny cards are great on the fly, our service one-sheeters and fact sheets work much better for presentations. These are always just one page long. The front is the same for all of the fact sheets; it describes our consortium in a nutshell. We get the front printed by a print shop and then run the backside through a personal inkjet printer to add whatever content is needed. The service one-sheeters contain summaries for each service: what it is, who to contact, and the main talking points. The stakeholder fact sheets contain PALNI facts in a nutshell like cost savings, key initiatives, and how the school benefits from being part of PALNI.

When making a one-sheeter for a specific stakeholder, it should be connected to what your stakeholder cares about. So, for example, your CFO might not care about your reference statistics, but they would be interested in hearing about your ILL shares that saved the library from buying over 100 books last month.

For printing, online is generally going to be cheaper than local shops unless your marketing department has an exclusive agreement. 
Marketing departments have often made a deal with a local print shop; see if you can go through them for discounts. For online print vendors, here are three options I've used:

- Vistaprint (vistaprint.com) regularly runs 30-50\% off sales (never pay full price!) and the quality is good enough, especially for large displays like banners. We've usually paid only $\$ 30$ for our banners.

- Moo (moo.com) cards cost more but you can feel the quality. Our "What I do" cards were done through Moo, whereas the IR cards were produced by Vistaprint.

- Smartpress (smartpress.com) is what we used for the PALNI annual report. I liked them and felt like it was good quality, but it was hard to visualize how it would turn out without feeling the different types of paper. Local print shops usually have samples to look at so you have a better idea what the end product will be. I would have made our annual report less shiny and skipped the UV coating had I seen it in person.

The final pain point is, "I need more confidence!" This particularly relates to engaging with a variety of stakeholders. The first step in overcoming this is to know who they are. There are several strategies for knowing who they are:

- Have a stakeholder contact list with names and contact information, organized by what you would contact them about.

- Develop personas for each stakeholder. Personas include information about what that stakeholder does in their job, what they care about, what information they would be interested in hearing about, what stresses them out and keeps them up at night. It's about putting yourself in their shoes so you can talk about your services in a way they understand and care about.

The next step is to tailor your content to each set of stakeholders. I recommend deciding on a leading service or initiative that you want to champion for a year. Then choose two to three other services or initiatives that are second priority to discuss. Shape or spin your case for each of these services or initiatives to be of interest to a specific stakeholder. For example, say you want everyone to know about your 
ILL service. The CFO will care more about cost-savings of ILL, whereas the faculty will care about quick shipping of materials and long loan rates. You need to be able to talk about the same services in multiple ways that match the interests of your audience. Remember, librarians do so many things that it can overwhelm people quickly to talk about everything. Talk about a single service or project that would interest them. Include a list of other projects and services in a follow-up email or a "leave behind" information sheet.

I don't recommend leading with your annual report. It's too much information. Give them a bite of what's important, give time to digest the bite, then let them discover the whole meal in a series of followups. Follow-ups are why "leave behinds" are key: they provide additional information and ways to contact you.

Now that you know who your stakeholders are and you've tailored your content, it's time to get in front of them. The first step is to get out of your office. Create opportunities to talk with them, even if it's not about the library. Join committees, offer to buy them lunch, etc. Fostering relationship will go a long way. Engaging stakeholders is a courtship, not an arranged marriage. One of our libraries has had a lot of success sponsoring coffee at their executive committee meetings in exchange for five minutes of their time to talk about a library service. Word of mouth marketing is the most successful marketing tactic. You can force this a bit by doing "planned word of mouth," which is also called influencer marketing. This involves having someone else who has a lot of sway championing your cause. The influencer depends on your stakeholder: whose opinion does the stakeholder value?

- For reaching faculty, try another faculty member or supervisor

- For reaching patrons, use alumni or the campus mascot

- To reach administrators, use alumni

One of the best word of mouth situations is when your campus marketing department covers your events. All administrators will likely see the stories the marketers run. Working with marketing departments can be tricky, however. Some marketing departments are overwhelmed with work, and the library just isn't a priority. Some are jerks and will flat out ignore you. Still, you don't know until you ask. Always ask if they will attend your event and take photos. If they 
are not able to, let them know that you'll be happy to send them some photos after the event for a write-up. Then do the work for them. If your campus marketers won't cover your event:

- Provide good photos of the event, even if it's just a few phone photos. Stories that include photos get posted far more often than stories that just contain text.

- Do the draft write-up of the story. It's easier for them to edit a story than to write it from scratch.

- Include student quotes/testimonials. This always catches their attention.

- In my experience, marketing departments are always under a tight deadline and running way behind. If I submit a draft story with some photos, they usually trim it down a bit and happily post it.

With these strategies to address the three primary pain points, I hope you will be able to successfully market your library to a variety of stakeholders. 